\title{
Effect of Indigenous Pseudomonas chlororaphis Strains on Morphological and Main Chemical Growth Parameters of Basil (Ocimum basilicum L.)
}

\author{
Aleksandra Stanojković-Sebić ${ }^{\prime *} \cdot$ Zoran Dinić $^{1} \cdot$ Renata Iličić ${ }^{2} \cdot$ Radmila Pivić ${ }^{1}$ Dragana Jošić \\ ${ }^{1}$ Institute of Soil Science, Teodora Drajzera 7, 11000 Belgrade, Serbia \\ ${ }^{2}$ Faculty of Agriculture, University of Novi Sad, Trg Dositeja Obradovića 8, 21000 Novi Sad, Serbia
}

\begin{abstract}
Summary: This study examined the effect of two indigenous plant growth promoting rhizobacterial strains of $P$. chlororaphis (Q16 and B25) on morphological (plant height; root length; number of leaves, buds and lateral branches) and main chemical (contents of N, P, K, Ca, Mg) growth parameters of two basil cultivars (Italiano classico and SRX 1920). The experiment was conducted in pots under glasshouse conditions from March to July 2014. Phosphorus was determined by spectrophotometer, potassium by flame emission photometry, nitrogen by using elemental CNS analyzer Vario EL III, while calcium and magnesium were determined by AAS. The obtained results showed that the treatment of basil cultivars with both $P$. chlororaphis strains had positive effect on all studied growth basil parameters in relation to the control, whereby the strain B25 was more effective than Q16. Concluding, tested P. chlororaphis strains have high potential in promoting the morphological and main chemical growth parameters of basil.

Keywords: basil, chemical growth parameters, growth, morphological characteristics, PGPR, plant growth stimulants, pot experiments, Pseudomonas chlororaphis, strains
\end{abstract}

\section{Introduction}

Basil (Ocimum basilicum L.) is the most common species in Lamiaceae family. This family includes 3500 species distributed between the genders as herbaceous plants, sometimes shrubs, but rarely as trees, with a significant content of essential oils. Ocimum genus includes about 150 species (Pushpangadan \& Bradu, 1995) and within the species Ocimum basilicum L. there are a number of varieties that differ in the general morphological structure and texture, and in the content of chemical parameters (Grayer et al., 1996). The basil plant (Basilici herba) is used in traditional and homeopathic medicine to treat a number of diseases. The essential oil of basil (Basilici aetheroleum) is used in the food, perfumery and cosmetics industry and has expressed bactericidal, fungicidal, antiviral, repellent, antioxidant, antidiarrhoeal, chemopreventive and radioprotective activity (Opalchenova \& Obreshkova, 2003; Pascual-Villalobos \& Ballesta-Acosta, 2003; Chiang et al., 2005; Božin et al., 2006; Gutierrez et al.,

Corresponding author:

astanojkovic@yahoo.com

Acknowledgments:

This study was conducted as a part of the project III 46007 "New indigenous bacterial isolates Lysobacter and Pseudomonas as an important sources of metabolites useful for biotechnology, plant growth stimulation and disease control: from isolates to inoculants", financially supported by the Ministry of Education, Science and Technological Development of the Republic of Serbia.
2008; Lukmanul Hakkim et al., 2008; Gajula et al., 2009; Dambolena et al., 2010; Runyoro et al., 2010).

The useful parts of the plants are leaves and seeds. Hot tea of basil plant leaves is good for treating nausea, dysentery, and flatulence. Externally, basil formulations can be used for different skin infections such as treatment of acne, snake bites and insect stings. In addition to these, basil has been used as a remedy for an enormous number of ailments, including cancer, convulsion, deafness, diarrhea, epilepsy, insanity, sore throat, toothaches, and whooping cough (Khatri et al., 1995).

Many medicinal and aromatic plants, including basil, are typically consumed without further processing after harvest and it is important that chemicals are not present in or on any part of the plant (Banchio et al., 2008). Therefore it is essential to identify the growth measurements of basil grown avoiding the chemical fertilizers and pesticides and achieving optimal growth and yields. Nowadays, the use of biofertilizers in production plays an important role as a supplement to improve the growth and yield of several agricultural, horticultural and medicinal plants (Murthy et al., 1998; Lugtenberg \& Kamilova, 2009). This biological approach is nevertheless considered to be more environment friendly in the long term.

One of the emerging research areas for improving the plant growth and yield, as well as for the control of different phytopathogenic agents, is the use of plant growth promoting rhizobacteria (PGPR). They are able to improve plant growth by increasing the rate of seed 
germination and seedling emergence, minimizing the adverse effects of external stress factors, and protecting plants from soil-borne pests and diseases. In this respect, different isolates of fluorescent Pseudomonas species take prominent place. Consequently, these isolates have been intensively studied (Couillerot et al., 2009; Ivanović et al., 2009; Jošić et al., 2012; Jošić et al., 2015; Zdravković et al., 2015; Mrkovački et al., 2016).

Fluorescent Pseudomonas chlororaphis belongs to PGPR because of the ability to colonize the plants roots and stimulate growth by decreasing the frequency of diseases (Couillerot et al., 2009). It uses various mechanisms such as production of antibiotics, HCN, plant hormones, asymbiotic fixation of $\mathrm{N}_{2}$, antagonism towards phytopathogenic microorganisms and the ability to solubilize mineral phosphates and other nutrients (Cattelan et al., 1999).

Regarding the preceding comments, the aim of this study was to examine the effect of two indigenous $P$. chlororaphis strains (Q16 and B25) on morphological (plant height, root length, number of leaves, number of the lateral branches, number of buds) and main chemical (content of $\mathrm{N}, \mathrm{P}, \mathrm{K}, \mathrm{Ca}$ and $\mathrm{Mg}$ ) growth parameters of two basil (Ocimum basilicum L.) cultivars.

\section{Materials and Methods}

The bacterial strains Pseudomonas chlororaphis Q16 and B25 were isolated from different host plants in Serbia. Taxonomic characterization of the isolates was based on tests for Gram staining, cytochrome oxidase, catalase, fermentation/utilization of glucose, lactose and sucrose, utilization of citrate, ability to degrade urea and 16S rDNA analyses (Ivanović et al., 2009; Jošić et al., 2012; Jošić et al., 2015). The bacteria were grown in liquid King's B medium (KB) for 24 h on orbital shaker at $120 \mathrm{rpm}$. Concentrations were determined spectrophotometrically $\left(\mathrm{OD}_{600}\right)$ and all experiments were conducted using $10^{6} \mathrm{CFUml}^{-1}$.

\section{Plant material and pot experiments}

The effect of PGP rhizobacteria was studied on two basil (Ocimum basilicum L.) cultivars: Italiano classico and SRX 1920, in pot experiments under semi-controlled conditions in the glasshouse of the Institute of Soil Science (Belgrade). The experiment was conducted during the first week of March until the first week of July in 2014, in plastic pots with $1.4 \mathrm{~kg}$ of homogenized soil - Fluvisol (WRB 2014). Three experimental variants for both cultivars were set up in five replications: 1. Control (V1); 2. P. chlororaphis - strain Q16 (V2); 3. P. chlororaphis strain B25 (V3). In every plastic pot five basil seeds were sown and after emergence two plants per pot were left. The inoculation of the soil and basil plants in each pot with $10 \mathrm{ml}$ of liquid inoculum of $P$. chlororaphis strains Q16 and B25 was performed during the last week of March in the phase of rooting, and another treatment during the first week of May, in the phase of tree growth. Control was treated with the same volume of distilled water as V2 and V3 treatment.

\section{Soil preparation and analysis}

The soil samples were air-dried, crushed and passed through a sieve $(\leq 2 \mathrm{~mm})$. Before setting up the experiment soil physical and chemical properties were studied. Soil granulometric composition was analyzed by determination of particle size distribution in mineral soil material, using the standardized method by sieving and sedimentation (ISO 11277:2009(E) 2009). Chemical soil properties were determined using the following chemical analyses: soil acidity $\left(\mathrm{pH}\right.$ in $\mathrm{H}_{2} \mathrm{O}$ and $1 \mathrm{M} \mathrm{KCl}$, v/v - soil: $\mathrm{H}_{2} \mathrm{O}=1: 5$, soil: $\left.1 \mathrm{M} \mathrm{KCl}=1: 5\right)$ was analyzed potentiometrically, using glass electrode (SRPS ISO 10390:2007 2007); total N and C content were analyzed on elemental CNS analyzer Vario EL III (Nelson \& Sommers, 1996), whereby the content of humus was calculated on the basis of $\mathrm{C}$ content according to Džamić et al. (1996), using the following formula: humus $(\%)=\mathrm{C}$ $(\%) \times 1.724$ (factor for conversion of organic $\mathrm{C}$ content to humus); available $\mathrm{P}_{2} \mathrm{O}_{5}(\mathrm{P})$ and $\mathrm{K}_{2} \mathrm{O}(\mathrm{K})$ were analyzed by Al-method according to Egner-Riehm (Riehm 1958), where $\mathrm{K}$ was determined by flame emission photometry and $\mathrm{P}$ by spectrophotometer after color development with ammonium molybdate and stannous chloride. The total content of $\mathrm{CaCO}_{3}$ was determined using the "rapid titration method" by Piper (van Reeuwijk, 2002).

\section{Preparation and analysis of the plant material}

Basil seedlings were grown according to the standard growing methods until 2 July, when all studied relevant parameters of the plant growth were measured, namely: plant height, root length, number of leaves, number of buds (if there were any) and number of the lateral branches. The basil plants were dried at $105^{\circ} \mathrm{C}$ for a period of 2 hours, using gravimetric method for determination of dry matter content of plant tissue (Miller, 1998), and weighed. For all plant samples of all treatments and replicates the following main chemical growth parameters of the aerial plant parts were analyzed: nitrogen $(\mathrm{N})$ was analyzed on elemental CNS analyzer Vario EL III (Nelson \& Sommers 1996); phosphorus $(\mathrm{P})$ and potassium $(\mathrm{K})$ contents were determined by method named as "wet" combustion, i.e. they were heated to boiling with the mixture of concentrated acids: $\mathrm{H}_{2} \mathrm{SO}_{4}$ and $\mathrm{HClO}_{4}$ (in the obtained solution, $\mathrm{P}$ was determined by spectrophotometer with molybdate, and $\mathrm{K}$ - by flame emission photometry) (Jakovljević et al., 1985); calcium (Ca) and magnesium $(\mathrm{Mg})$ were determined by Atomic Absorption Spectrometry (AAS) (Wright \& Stuczynski, 1996), where the plant material was converted to a solution by method named as "dry" combustion, i.e., first by heating at $550^{\circ} \mathrm{C}$ (for several hours) and then by treating the obtained ash with hydrochloric acid (Miller, 1998a). 


\section{Data analysis}

The obtained data on soil properties represent the arithmetic means of three replicates and standard deviation values. The effects of V1, V2 and V3 treatments on the studied morphological and chemical parameters of the plants were evaluated us-ing the analysis of variance (SPSS 20.0, Chicago, USA), followed by Duncan's Multiple Range Test (DMRT). Significant differences between means were tested by the $\mathrm{LSD}$ test at $\mathrm{P}=0.05$.

\section{Results and Discussion}

\section{Soil properties}

Table 1 displays the results of soil physical and chemical properties. The studied Fluvisol is a sandy loam according to the soil textural class determined on the basis of particle size distribution, having alkaline reaction, low carbonates and medium humus content, with a high content of available phosphorus and medium provided with available potassium. It belongs to the third soil capability class, which includes the soils used for crop production, but with certain limitations. Improvement of the water, air and thermal regime, along with ensuring the available nutrients, high and stable yields of cultivated plants can be achieved on such soils (Škorić et al., 1985).

\section{Morphological and chemical growth parameters of plants}

Table 2 displays the data on morphological growth parameters of basil cultivars influenced by the treatment applied.

In general, certain effects of both strains on basil growth were noticed immediately after the second treatment while the plants were still in pots. The data on studied morphological parameters at the end of experiment showed that the treatment of basil cultivars with both $P$. chlororaphis strains had positive effect on all parameters in relation to the control, whereby the B25 was more effective than Q16. The highest plants and number of leaves were obtained by applying B25 strain, but its influence was not statistically significant. Statistically significant positive effect of both strains was registered in root length, with better effect of B25 than Q16 (Table 2). The average values of V2 and V3 treatment were close to the control and did not influence the number of lateral branches. The buds were not observed. The promotion and increase of growth parameters of basil (plant growth and root length), when inoculated with PGPR strains, was also previously reported (Vinutha, 2005; Hemavathi et al., 2006).

Table 3 displays the data on chemical growth parameters (available macroelements) in basil cultivars influenced by the treatment applied.

The obtained results of $\mathrm{N}, \mathrm{P}, \mathrm{K}, \mathrm{Ca}$ and $\mathrm{Mg}$ contents were in accordance with morphological parameters, meaning that the content of these elements was the highest in both basil cultivars treated with B25 strain. This influence was statistically significant regarding the content of $\mathrm{N}$ and $\mathrm{P}$ in both cultivars (Table 2). On the other hand, statistically significant positive effect of strain Q16 was registered only in $\mathrm{N}$ content in both basil cultivars (Table 2). This rationale is consistent with the observation that plants inoculated with PGPR take up N, P, K and microelements more efficiently from the soil (Cakmakci et al., 2005). Improved mineral nutrition would explain the promotion of root and plant growth. The increase in N, $\mathrm{P}$ and $\mathrm{K}$ content in Ocimum basilicum inoculated with

Table 1. Physical and chemical properties of Fluvisol

\begin{tabular}{|c|c|}
\hline Granulometric composition & \multirow{2}{*}{ Value } \\
\hline Fraction $(\%)$ & \\
\hline Bulky sand, 2-0.2 mm & 0.30 \\
\hline Miniature sand, $0.2-0.02 \mathrm{~mm}$ & 61.5 \\
\hline Dust, $0.02-0.002 \mathrm{~mm}$ & 19.7 \\
\hline Clay, $<0.002 \mathrm{~mm}$ & 18.5 \\
\hline Total sand, $>0.02 \mathrm{~mm}$ & 61.8 \\
\hline Dust + clay, $<0.02 \mathrm{~mm}$ & 38.2 \\
\hline Chemical properties & Value (means \pm standard deviation) \\
\hline $\mathrm{pH}$ in $\mathrm{H}_{2} \mathrm{O}$ & $7.89 \pm 0.03$ \\
\hline $\mathrm{pH}$ in $1 \mathrm{M} \mathrm{KCl}$ & $7.50 \pm 0.03$ \\
\hline Total content $\mathrm{CaCO}_{3}(\%)$ & $9.50 \pm 0.05$ \\
\hline Total N (\%) & $0.09 \pm 0.01$ \\
\hline Humus $(\%)$ & $1.83 \pm 0.02$ \\
\hline Available $\mathrm{P}_{2} \mathrm{O}_{5}\left(\mathrm{mg} 100 \mathrm{~g}^{-1}\right)$ & $22.06 \pm 0.22$ \\
\hline Available $\mathrm{K}_{2} \mathrm{O}\left(\mathrm{mg} 100 \mathrm{~g}^{-1}\right)$ & $16.00 \pm 0.83$ \\
\hline
\end{tabular}


Table 2. Morphological growth parameters of basil cultivars depending on the treatment

\begin{tabular}{|c|c|c|c|c|}
\hline Variants & Plant height $(\mathrm{cm})$ & Root length $(\mathrm{cm})$ & Number of leaves & Number of lateral branches \\
\hline \multicolumn{5}{|l|}{ Italiano classico } \\
\hline V1 - control & $11.52 \pm 3.48^{\mathrm{a}}$ & $6.41 \pm 0.63^{\mathrm{a}}$ & $11.00 \pm 2.12^{\mathrm{a}}$ & $4.80 \pm 0.76^{\mathrm{a}}$ \\
\hline V2 - strain Q16 & $13.69 \pm 1.58^{\mathrm{a}}$ & $7.51 \pm 0.39 \mathrm{~b}$ & $11.60 \pm 0.55^{\mathrm{a}}$ & $4.90 \pm 0.22^{\mathrm{a}}$ \\
\hline V3 - strain B25 & $14.10 \pm 2.66^{\mathrm{a}}$ & $9.46 \pm 1.04 \mathrm{c}$ & $12.60 \pm 0.55^{\mathrm{a}}$ & $5.70 \pm 0.27 \mathrm{a}$ \\
\hline$P$ value & NSD & $* * *$ & NSD & NSD \\
\hline $\operatorname{LSD}(0.05)$ & 3.708 & 1.019 & 1.796 & 0.782 \\
\hline \multicolumn{5}{|l|}{ SRX 1920} \\
\hline V1 - control & $11.52 \pm 3.48^{a}$ & $7.20 \pm 0.61 \mathrm{~b}$ & $11.40 \pm 1.52^{\mathrm{a}}$ & $4.80 \pm 0.57 \mathrm{a}$ \\
\hline V2 - strain Q16 & $13.69 \pm 1.58^{\mathrm{a}}$ & $7.52 \pm 1.17 \mathrm{~b}$ & $11.00 \pm 2.35^{\mathrm{a}}$ & $4.90 \pm 0.89 \mathrm{a}$ \\
\hline V3 - strain B25 & $14.10 \pm 2.66^{\mathrm{a}}$ & $9.45 \pm 1.45^{\mathrm{a}}$ & $12.00 \pm 0.71^{\mathrm{a}}$ & $5.20 \pm 0.57^{a}$ \\
\hline$P$ value & NSD & * & NSD & NSD \\
\hline $\operatorname{LSD}(0.05)$ & 3.708 & 1.559 & 2.292 & 0.763 \\
\hline
\end{tabular}

LSD - least significant differences at $\mathrm{P}=0.05$; *** - statistical significant differences at the $\mathrm{P}<0.05, \mathrm{P}<0.01$ and $\mathrm{P}<0.001$ levels, respectively; NSD statistically not significant; DMRT was used to compare different variants at $\mathrm{P} \leq 0.05$, where values followed by the same letter in a column are not significantly different.

Table 3. Available macroelements in basil cultivars depending on the treatment

\begin{tabular}{|c|c|c|c|c|c|}
\hline Variants & $\mathrm{N}(\%)$ & $\mathrm{P}_{2} \mathrm{O}_{5}(\%)$ & $\mathrm{K}_{2} \mathrm{O}(\%)$ & $\mathrm{Ca}(\%)$ & $\operatorname{Mg}(\%)$ \\
\hline \multicolumn{6}{|l|}{ Italiano classico } \\
\hline V1-control & $3.31 \pm 0.08^{\mathrm{a}}$ & $0.61 \pm 0.02^{\mathrm{b}}$ & $3.64 \pm 0.17 \mathrm{a}$ & $3.08 \pm 0.04^{a}$ & $0.50 \pm 0.04^{a}$ \\
\hline V2-strain Q16 & $3.54 \pm 0.11^{\mathrm{b}}$ & $0.61 \pm 0.04^{\mathrm{b}}$ & $3.72 \pm 0.07 \mathrm{a}$ & $3.18 \pm 0.19^{a}$ & $0.55 \pm 0.06^{\mathrm{a}}$ \\
\hline V3-strain B25 & $4.22 \pm 0.12^{\mathrm{c}}$ & $0.70 \pm 0.04^{a}$ & $3.82 \pm 0.09^{a}$ & $3.24 \pm 0.10^{a}$ & $0.57 \pm 0.06^{\mathrm{a}}$ \\
\hline$P$ value & $* * *$ & $* *$ & NSD & $*$ & NSD \\
\hline $\operatorname{LSD}(0.05)$ & 0.15 & 0.05 & 0.18 & 0.15 & 0.07 \\
\hline \multicolumn{6}{|l|}{ SRX 1920} \\
\hline V1-control & $3.14 \pm 0.12^{\mathrm{a}}$ & $0.62 \pm 0.02^{\mathrm{b}}$ & $3.48 \pm 0.11^{\mathrm{a}}$ & $3.09 \pm 0.07 \mathrm{a}$ & $0.52 \pm 0.03^{\mathrm{a}}$ \\
\hline V2-strain Q16 & $3.42 \pm 0.06^{\mathrm{b}}$ & $0.65 \pm 0.03 \mathrm{~b}$ & $3.59 \pm 0.09 \mathrm{a}$ & $3.18 \pm 0.14 \mathrm{a}$ & $0.54 \pm 0.04 a$ \\
\hline V3-strain B25 & $4.52 \pm 0.09 \mathrm{c}$ & $0.88 \pm 0.09 a$ & $3.60 \pm 0.02^{\mathrm{a}}$ & $3.27 \pm 0.15^{\mathrm{a}}$ & $0.55 \pm 0.05^{\mathrm{a}}$ \\
\hline$P$ value & $* * *$ & $* * *$ & $* *$ & NSD & NSD \\
\hline $\operatorname{LSD}(0.05)$ & 0.09 & 0.08 & 0.84 & 0.17 & 0.05 \\
\hline
\end{tabular}

LSD - least significant differences at $\mathrm{P}=0.05$; *** - statistical significant differences at the $\mathrm{P}<0.05, \mathrm{P}<0.01$ and $\mathrm{P}<0.001$ levels, respectively; NSD statistically not significant; DMRT was used to compare different variants at $\mathrm{P} \leq 0.05$, where values followed by the same letter in a column are not significantly different.

PGPR Pseudomonas putida and Arotobacter chroococcum was previously reported (Ordookhani et al., 2011).

In addition, as stated by the other authors (Zdravković et al., 2015), and as it was done in this study, it is suggested that bacterial suspension should be applied during the growth phase of plants when the treatment has the greatest impact, i.e. when enzyme activity is the strongest.

\section{Conclusions}

The data on the studied morphological and chemical growth parameters of basil cultivars showed that their treatment with both P. chlororaphis strains had positive effect on all parameters in relation to the control, although this influence was statistically significant only regarding the root length and the content of $\mathrm{N}$ and $\mathrm{P}$ in both cultivars, with better effect of B25 strain than Q16 strain. Also, statistically significant positive effect of strain Q16 was registered in $\mathrm{N}$ content in both basil cultivars. In addition, studied $P$. chlororaphis strains have high potential in promoting the morphological and main chemical growth parameters of basil. Also, bacterial suspension should be applied during the plants growth phase when an enzyme activity is the strongest.

\section{References}

Banchio, E., Bogino, P. C., Zygadlo, J., \& Giordano, W. (2008). Plant growth promoting rhizobacteria improve growth and essential oil yield in Origanum majorana L. Biochemical Systematics and Ecology, 36, 766-771.

Božin, B., Mimica-Dukić, N., Simin, N., \& Anackov, G. (2006). Characterization of the volatile composition of essential oils of some Lamiaceae spices and the antimicrobial and antioxidant activities of the entire oils. Journal of Agricultural and Food Chemistry, 54, 1882-1828. 
Cakmakci, R., Donmez, D., Aydýn, A., \& Sahin, F. (2005). Growth promotion of plants by plant growth-promoting rhizobacteria under greenhouse and two different field soil conditions. Soil Biology and Biochemistry, 38, 1482-1487.

Cattelan, A. J., Hartel, P. G., \& Fuhrmann, J. J. (1999). Screening for plant growth-promoting rhizobacteria to promote early soybean growth. Soil Science Society of America Journal, 63, 1670 1680.

Chiang, L. C., Cheng, P. W., Chaiang, W., \& Lin, C. (2005). Antiviral activities of extracts and selected pure constittents of Ocimum basilicum. Clinical and Experimental Pharmacology and Physiology, 32, 811-816.

Couillerot, O., Prigent-Combaret, C., Caballero-Mellado, J., \& Moënne-Loccoz, Y. (2009). Pseudomonas fluorescens and closely related fluorescent pseudomonads as biocontrol agents of soil -borne phytopathogens. Letters in Applied Microbiology, 48, 505512 .

Dambolena, J. S., Zunino, M. P., López, A. G., Rubinstein, H. R., Zygadlo, J. A., Mwangi, J. W., ... Kariuki, S. T. (2010). Essential oils composition of Ocimum basilicum L. and Ocimum gratissimum L. from Kenya and their inhibitory effects on growth and fumonisin production by Fusarium verticillioides. Innovative Food Science and Emerging Technologies, 11, 410-414.

Gajula, D., Verghese, M., Boateng, J., Walker, L. T., Schackelford, L., Mentreddy, S. R., \& Cedric, S. (2009). Determination of total phenolics, flavonoids, and antioxidant and chemopreventive potential of basil (Ocimum basilicum L. and Ocimum tenuiflorum L.). International Journal of Cancer Research, 5, 130-143.

Grayer, R. J., Kite, G. C., Goldstone, J., Bryan, S. E., Paton, A., \& Putievsky, E. (1996). Intraspecific taxonomy and essential oil chemotypes in sweet basil, Ocimum basilicum. Phytochemistry, 43, 1033-1039.

Gutierrez, J., Barry-Ryan, C., \& Bourke, P. (2008). The antimicrobial efficacy of plants oils combinations and interactions with food ingredients. International Journal of Food Microbiology, 124, 91-97.

Hemavathi, V. N., Sivakumr, B. S., Suresh, C. K., \& Earanna, N. (2006). Effect of Glomus fasciculatum and plant growth promoting rhizobacteria on growth and yield of Ocimum basilicum. Karnataka Journal of Agricultural Sciences, 19, 17-20.

ISO 11277: 2009(E) (2009). Soil quality - determination of particle size distribution in mineral soil material - method by sieving and sedimentation. Geneva, Switzerland, International Organization for Standardization.

Ivanović, Ž., Živković, S., Starović, M., Jošić, D., Stanković, S., \& Gavrilović, V. (2009). Diversity among Pseudomonas syringae strains originating from fruit trees in Serbia. Archives of Biological Sciences, 61, 863-870.

Jakovljević, M., Pantović, M., \& Blagojević, S. (1985). Laboratory Manual in Chemistry of Soils and Waters (In Serbian). University of Belgrade, Faculty of Agriculture, Belgrade, Serbia.

Jošić, D., Protolipac, K., Starović, M., Stojanović, S., Pavlović, S. Miladinović, M., \& Radović, S. (2012). Phenazines producing Pseudomonas isolates decrease Alternaria tenuissima growth, pathogenicity and disease incidence on cardoon. Archives of Biological Sciences (Belgrade), 64, 1495-1503

Jošić, D., Ćirić, A., Soković, M., Stanojković-Sebić, A., Pivić, R., Lepšanović, Z., \& Glamočlija, J. (2015). Antifungal activities of indigenous plant growth promoting Pseudomonas spp. from alfalfa and clover rhizosphere. Frontiers in Life Science, 8, 131138.

Khatri, M., Nasir, M. K. A., Saleem, R., \& Noor, F. (1995). Evaluation of Pakistani sweet basil oil for commercial exploitation. Pakistan Journal of Scientific and Industrial Research, 38, 281-282.

Lugtenberg, B., \& Kamilova, F. (2009). Plant growth-promoting rhizobacteria. Annual Review of Microbiology, 63, 541-556.
Lukmanul Hakkim, F., Arivazhagan, G., \& Boopathy, R. (2008) Antioxidant property of selected Ocimum spices and their secondary metabolite content. Journal of Medicinal Plants Research, 2, 250-257.

Miller, R. (1998). Determination of dry matter content of plant tissue: gravimetric moisture. In: Y.P. Kalra (Ed.), Handbook of reference methods for plant analysis (pp. 51-52). Boca Raton, FL: CRC Press.

Miller, R. (1998a). High-temperature oxidation: dry ashing. In: Y. Kalra (Ed.), Handbook of reference methods for plant analysis (pp. 53-56). Boca Raton, FL: CRC Press.

Mrkovački, N., Đalović, I., Jošić, D., Bjelić, D., \& BrdarJokanović, M. (2016). The effect of PGPR strains on microbial abundance in maize rhizosphere in field conditions. Ratarstvo i pourtarstvo, 53, 15-19.

Murthy, N. K., Srinivasan, S., \& Warrier, R. K. (1998). Effect of Azospirillum and Phosphobacterium in improving seed germination and vigour of Amla. Journal of Non Timber Forest Products, 6, 34-36.

Nelson, D. W., \& Sommers, L. E. (1996). Total carbon, organic carbon, and organic matter. In: D. L. Sparks (Ed.), Methods of Soil Analysis, 3 (pp. 961-1010). Madison, WI: SSSA.

Opalchenova, G., \& Obreshkova, D. (2003). Comparative studies on the activity of basil - an essential oil from Ocimum basilicum L. - against multridrug resistant clinical isolated of genera Staphylococus, Enterococcus and Pseudomonas by using different test methods. Journal of Microbiological Methods, 54, 105-110.

Ordookhani, K., Sharafzadeh, S., \& Zare, M. (2011). Influence of PGPR on growth, essential oil and nutrients uptake of sweet basil. Advances in Environmental Biology, 5, 672-677.

Pascual-Villalobos, M. J., \& Ballesta-Acosta, M. C. (2003). Chemical Variation in an Ocimun basilicum germplasm collection and activity of the essential oils on Callosobruchus maculatus. Biochemical Systematics and Ecology, 31, 673-679.

Pushpangadan, P., \& Bradu, B. L. (1995). Basil. In: K. L. Chadha, \& R. Gupta (Eds.),.Advances in horticulture. Medicinal and aromatic plants, 11 (pp. 627-657). New Delhi: Malhotra Publishing House.

Riehm, H. (1958). Die Ammoniumlaktatessigsäure-Methode zur Bestimmung der leichtlöslichen Phosphorsäure in Karbonathaltigen Böden. Agrochimica, 3, 49-65.

Runyoro, D., Ngassapa, O., Vagionas, K., Aligiannis, N., Graikou, K., \& Chinou, I. (2010). Chemical composition and antimicrobial activity essential oils of four Ocimum species growing in Tanzania. Food Chemistry, 119, 311-316.

SRPS ISO 10390: 2007 (2007). Soil quality - determination of $p H$. Belgrade, Serbia, Institute for Standardization of Serbia.

Škorić, A., Filipovski, G., \& Ćirić, M. (1985). Classification of Soils of Yugoslavia (In Bosnian). Academy of Sciences and Arts of Bosnia and Herzegovina, Sarajevo.

van Reeuwijk, L. P. (2002). Carbonate. In: Procedures for soil analysis, $6^{\text {th }}$ ed (pp. 7-8). Wageningen, The Netherlands, International Soil Reference and Information Centre.

Vinutha, T. (2005). Biochemical studies on Ocimum sp. inoculated with microbial inoculants. MSc Thesis. University of Agricultural Sciences, Bangalore, India.

Wright, R. J., \& Stuczynski, T. (1996). Atomic absorption and flame emission spectrometry. In: D.L. Sparks (Ed.), Methods of Soil Analysis, 3 (pp. 65-90). Madison, WI: SSSA.

WRB (2014). World Reference Base for Soil Resources - International soil classification system for naming soils and creating legends for soil maps. Rome, Italy, Food and Agriculture Organization of the United Nations. http://www.fao.org/3/a-i3794e.pdf.

Zdravković, J., Ugrinović, M., Zdravkovic, M., Đordević, S., Pavlović, S., \& Jošić, D. (2015). In vitro and in vivo effects of Pseudomonas spp. and Bacillus sp. on Fusarium acuminatum, Botrytis cinerea and Aspergillus niger infecting cucumber. Pesticides and Phytomedicine (Belgrade), 30, 169-178. 


\section{Uticaj autohtonih sojeva Pseudomonas chlororaphis na morfološke i osnovne hemijske parametre rasta bosiljka (Ocimum basilicum L.)}

\section{Aleksandra Stanojković-Sebić · Zoran Dinić · Renata Iličić · Radmila Pivić · Dragana Jošić}

Sažetak: Ispitivan je uticaj dva autohtona soja Pseudomonas chlororaphis (Q16 and B25) na morfološke (visina biljke, dužina korena, broj listova, broj pupoljaka i broj bočnih grana) i osnovne hemijske (sadržaj azota, fosfora, kalijuma, kalcijuma i magnezijuma) parametre rasta dve sorte bosiljka (Ocimum basilicum L.): Italiano classico i SRX 1920. Ogled je izveden $u$ vegetacionim sudovima $u$ periodu od marta do jula 2014. godine. Fosfor je određen spektrofotometrijski, kalijum plamenom emisionom fotometrijom, azot na elementarnom CNS analajzeru Vario EL III, dok su kalcijum i magnezijum određeni atomskom apsorpcionom spektrometrijom. Dobijeni rezultati su pokazali da je tretman testiranih sorti bosiljka sa oba soja P. chlororaphis imao pozitivan uticaj na sve ispitivane parametre rasta ove biljne vrste u odnosu na kontrolu, pri čemu je soj B25 bio efikasniji od Q16 soja. Može se zaključiti da testirani sojevi $P$. chlororaphis imaju veliki potencijal u promovisanju morfoloških i osnovnih hemijskih parametara rasta bosilika.

Ključne reči: bosiljak, hemijski parametri rasta, morfološke karakteristike, PGPR, Pseudomonas chlororaphis, rast, stimulanti rasta biljaka, sojevi, vegetacioni ogled 